\title{
PALEOMAGNETISM OF THE CEARÁ-MIRIM DYKE SWARM, NORTHEASTERN BRAZIL
}

\author{
M.Ernesto ${ }^{1}$ \\ M.H.Furtado ${ }^{2}$ \\ J.W.P.Macedo ${ }^{3}$ \\ G.Martins ${ }^{4}$
}

The Mesozoic tholeiitic Ceará-Mirim dyke swarm has a general east-west trend cutting the Precambrian basement of northeastern Brazil. The dykes occur mainly in the State of Rio Grande do Norte (RN) but enter the neighbouring State of Ceará to the west where they trend SW-NE (Fig. 1 ). This swarm was subdivided into six parallel sub-swarms by SIAL $(1975,1976)$ who attributed an Early Cretaceous age to them. Available K-Ar radiometric dates (EBERT \& BROCHINI, 1968; CORDANI, 1974; RODRIGUES, 1976; SIAL, 1976; HORN et al., 1988; MACEDO, unpublished data) vary between 214 and $216 \mathrm{Ma}$. HORN et al. (1988) used a procedure which allowed the removal of argon-loss effects to conclude that the ages might be situated between Middle Jurassic and Early Cretaceous. Paleomagnetic data presented by GUERREIRO \& SCHULT (1983) and BUCKER et al. (1986), corresponding to samples from the eastern part of the swarm (between the cities of Lages and Angicos, RN), suggest that the emplacement of the sub-swarms was not simultaneous since they show distinct magnetization directions.

New paleomagnetic results that confirm the above conclusion are presented here for the western part of the swarm, where the dykes show a SW-NE structural orientation. Five parallel sub-swarms were identified, each with its characteristic magnetization direction (Fig. 2), although sub-

\footnotetext{
'Instituto Astronômico e Geofísico-IAG, Universidade de São Paulo, Caixa Postal 30627, 01051 São Paulo, SP, Brazil.

${ }^{2}$ Curso de Graduação em Geofísica - LAG/USP.

${ }^{3}$ Departamento de Física Teórica e Experimental, Universidade Federal do Rio Grande do Norte, Natal, RN, Brazil.

${ }^{4}$ Curso de Pós Graduação - LAG/USP, bolsista do CNPq.
} 


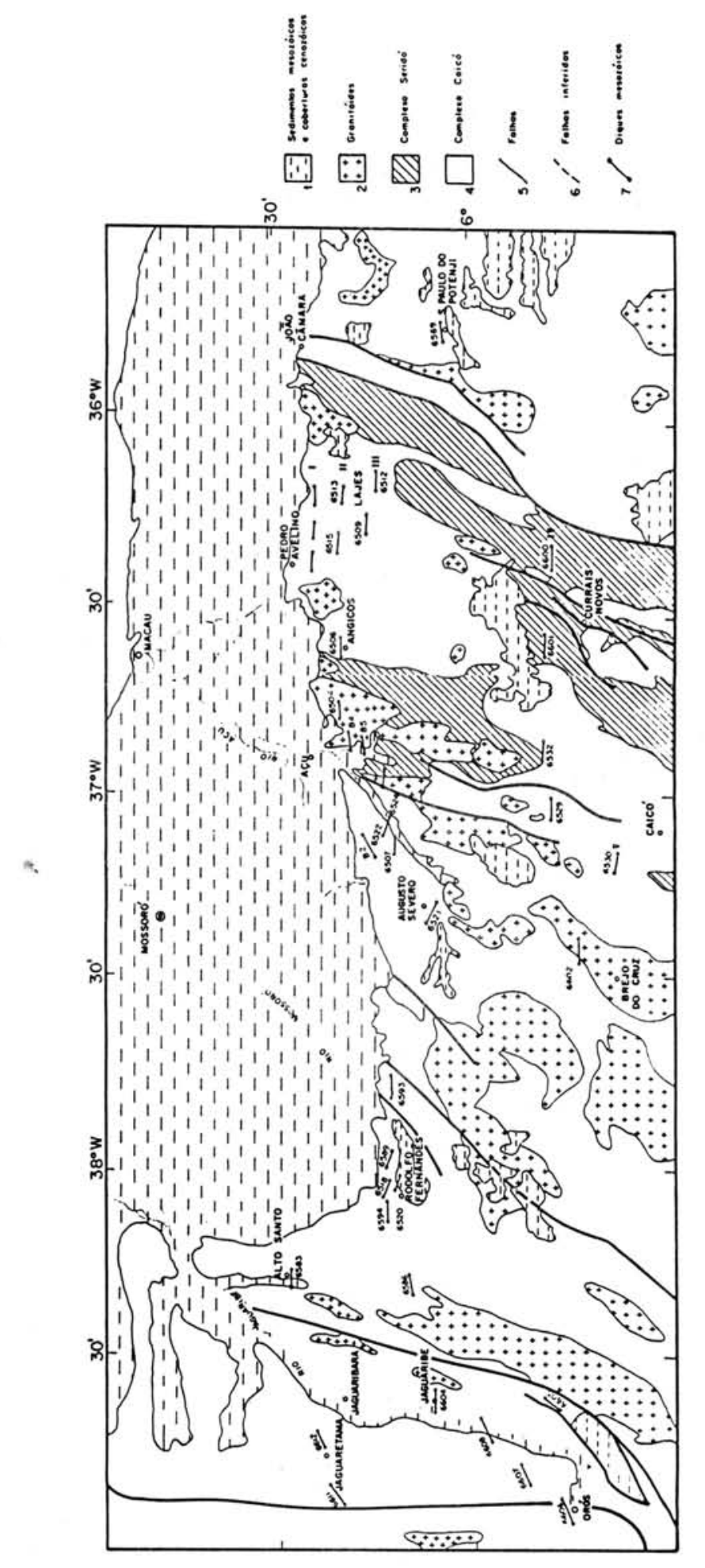

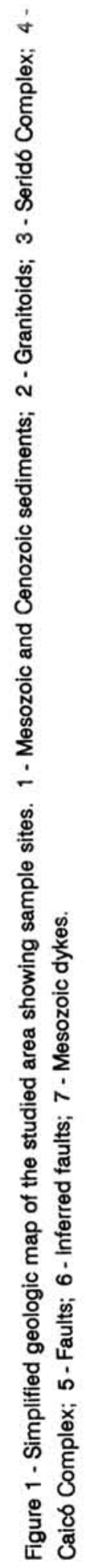




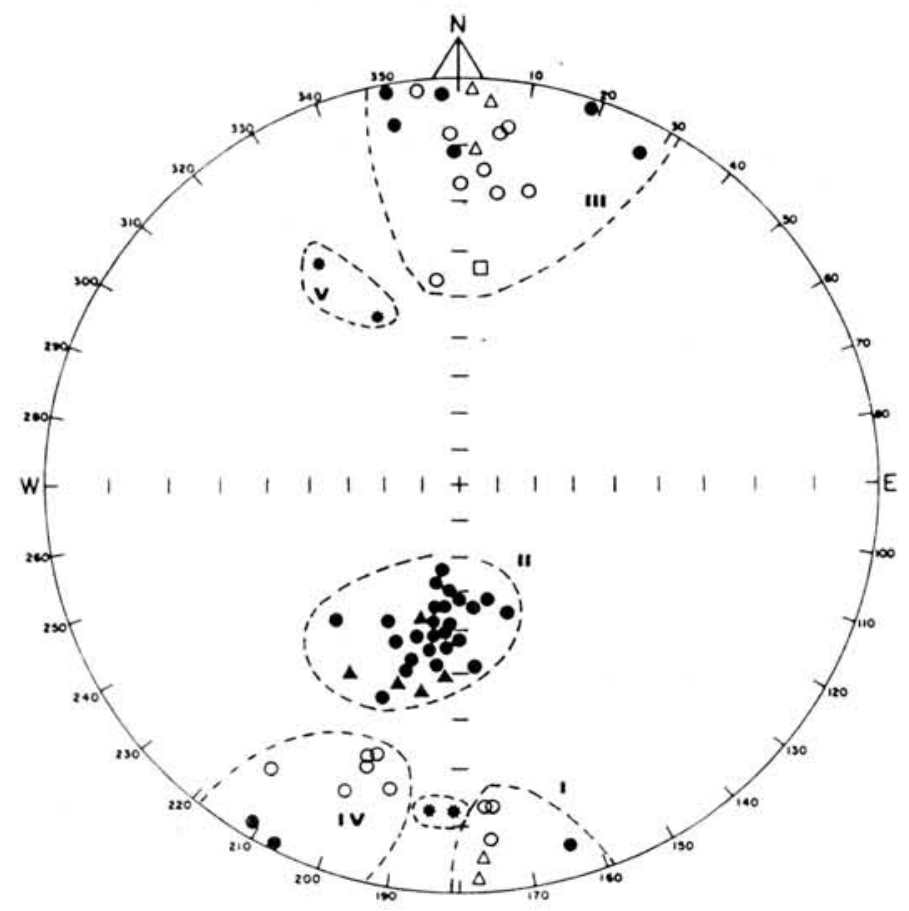

Figure 2 - Sample-mean directions of magnetization for the Ceara-Mirim dykes. Open symbols represent negative inclinations and solid symbols positive inclinations: triangles - results obtained by GUERREIRO \& SCHULT (1983); stars - alkaline rocks (sub-swarm V); square - host rock sample (RN-37).

swarm V is still not very well defined due to the scarcity of data.

The characteristic magnetizations of sub-swarms I, III and IV show differences which could have been caused by the long-term (some thousands of years) geomagnetic field variations during the cooling of the dykes. By combining the magnetization directions of these three sub-swarms, a paleomagnetic pole is calculated which is in accordance with other Late Jurassic-Early Cretaceous poles for South America.

However, sub-swarm II shows characteristic magnetization directions very distinct from the others, and its calculated paleomagnetic pole indicates an Early Jurassic age. This age is consistent with the K-Ar dates given by HORN et al. (1988) and supports the assumption that subswarm II is older than sub-swarms I, III and IV. 


\section{REFERENCES}

BUCKER, C.; SCHULT, A.; BLOCH, W.; GUERREIRO, S.D.C. (1986) Rock magnetism and paleomagnetism of an Early Cretaceous/Late Jurassic dike swarm in Rio Grande do Norte, Brazil. Journal of Geophysics, 60:129-135.

CORDANI, U.G. (1974) Comentários sobre as determinações geocronológicas disponiveis nas Folhas Natal e Recife. In: SCHOBBENHAUS Fo (coord.) Carta Geológica do Brasil ao milionésimo: Folha Natal (SB-25), Folha Recife (SC-25). Brasfia, DNPM. p.25-28.

EBERT, H. \& BROCHINI, M.F. (1968) Estudos estratigráficos e geocronológicos no escudo brasileiro. Clência e Cultura, 20(3):621-625.

GUERREIRO, S.D.C. \& SCHULT, A. (1983) Paleomagnetismo de um enxame de diques tolefíticos de idade meso-cenozóica, localizados no Rio Grande do Norte. Revista Brasileira de Geofísica, 1:89-98.

HORN, P.; MULLER-SOHNIUS, D.; SCHULT, A. (1988) Potassium-argon ages on a Mesozoic tholeiitic dike swarm in Rio Grande do Norte, Brazil. Revista Brasileira de Geociências, 18(1):50-53.

RODRIGUES, M.F.B. (1976) Rochas basálticas do Rio Grande do Norte e Paraíba. São Paulo, 62p. (Dissertação de Mestrado - Instituto de Geociências/USP).

SIAL, A.N. (1975) Petrologia e significado tectônico dos diabásios mesozóicos do Rio Grande do Norte e Paralba. In: SIMPÓSIO DE GEOLOGIA DO NORDESTE, 7., Fortaleza, 1975. Atas. Fortaleza, SBG. p.207-221.

SIAL, A.N. (1976) The post-paleozoic volcanism of northeast Brazil and its tectonic significance. Anais da Academia Brasileira de Ciências, 48:299-311. 